\title{
Comparison of Face-To-Face and Hybrid Delivery of a Course that Requires Technology Skills Development
}

\author{
Gary J. Senn \\ University of South Carolina Aiken, Aiken, SC, USA
}

SennG@sc.edu

\section{Executive Summary}

Online learning continues to be among the fastest-growing sectors of higher education. K-12 teachers and education professionals outside of the K-12 classroom are among the consumers taking interest in online learning. With many opportunities for technology-enriched learning, educators are becoming more interested in educational technology programs that will provide them with credentials necessary to serve in the growing areas of educational technology incorporation and online learning.

A degree program in educational technology was established that offered classes through a variety of delivery methods. Classes were delivered in face-to-face, online, and hybrid formats. Hybrid classes were offered with some portions online, some face-to-face and, in some cases, twoway, interactive video. To address needs for an increasing number of students who traveled for some distance to participate in the degree program, the faculty began moving the entire program online. Two classes were particularly difficult to move to an online format. These two design and development tools classes required the learning of skills related to specific software packages that were unfamiliar to most students. The classes required much practice with the software packages and much instructor support that included demonstration of skills and troubleshooting during the learning process.

This research explored student performance in and perceptions of a class that moved from faceto-face to hybrid delivery in the transition toward an online format. Student perceptions, activities, and preferences were used to group students into one of five categories: prefer online, prefer face-to-face, prefer hybrid, no preference, and online-strugglers. Brief case studies of one or two individuals from each group were described in this study to provide insight into the learning preferences and attitudes of students. A significant finding in this project was that a course with a high level of technology skills development and a significant requirement for hands-on practice was difficult to deliver in a hybrid format. Delivery of such a course required much more effort

from the instructor and created the perception by students that the course was

Material published as part of this publication, either on-line or in print, is copyrighted by the Informing Science Institute. Permission to make digital or paper copy of part or all of these works for personal or classroom use is granted without fee provided that the copies are not made or distributed for profit or commercial advantage AND that copies 1) bear this notice in full and 2) give the full citation on the first page. It is permissible to abstract these works so long as credit is given. To copy in all other cases or to republish or to post on a server or to redistribute to lists requires specific permission and payment of a fee. Contact 0HPublisher@InformingScience.org to request redistribution permission. more difficult.

Keywords: Blended Learning, ELearning, Online learning, Web-based learning, Learner satisfaction, Student Perceptions, Faculty Effort. 


\section{Introduction}

Online learning continues to be a leading growth sector in higher education (Allen \& Seaman, 2006; Foster \& Carnevale, 2007; Kim \& Bonk, 2006). The online learning movement demonstrated significant attention during the 1990s, but some institutions began to move away from online learning initiatives during the first few years of the 21 st Century because the interest level of students was not as high as anticipated. With the recent success of online universities and a variety of online programs, many public universities more recently have embraced online learning (Foster \& Carnevale, 2007). Student interest in taking online classes has also increased. "Nearly 3.2 million students were taking at least one online course during the fall 2005 term, a substantial increase over the 2.3 million reported the previous year" (Allen \& Seaman, 2006). Some research indicates that more part-time and younger students take online courses (Singh \& Pan, 2004). Some researchers suggest that online learning has created a true paradigmatic shift in the way people teach and learn (Bassoppo-Moyo, 2006; DeNeui \& Dodge, 2006). "The precise nature of the change is difficult to quantify, however allocation of sufficient time and resources, combined with managerial support, will help staff through the period of transition" (O'Neil, Singh, \& O'Donoghue, 2004).

Clearly, more students have enrolled in online classes, but student perceptions related to online courses have been mixed (Smart \& Cappel, 2006). According to Chen's research, "students felt that the Web-based instruction program was useful and they liked the Web treatment of the content" (2005, p. 75). In courses that required much individualized work, learner autonomy and self-regulation were related to student success in and positive perceptions of online learning (Huang, 2002; Reisetter, LaPointe, \& Korcuska, 2007). An area of interest related to online learning was research indicating that students preferred a hybrid course format that incorporated online activities with traditional, face-to-face delivery (Marcketti \& Yurchisin, 2005; Tang \& Byrne, 2007). A hybrid course is "not simply a matter of the combination of face-to-face and online instruction but it has to have elements of social interaction" (Heinze \& Procter, 2006, p. 247). Many studies reported that there was no significant difference in course outcomes when comparing conventional to online classes (Newlin, Lavooy, \& Wang, 2005; Papastrergiou, 2006; Shelley, Swartz, \& Cole, 2007). Some studies indicated that the lack of social interaction in online courses was a concern of students and that students who reported higher perceived social presence in a course also perceived that they learned more (MacGregor, 2001; Richardson \& Swan, 2003). Biggs, Simpson, and Walker (2006) reported that online students have lower perceptions of instructor support and student interactions in an online format. Other research indicated that group work enhanced online learning while students who worked alone were less motivated and had lower perceptions of learning (Hiltz, Coppola, Rotter, Turoff, \& Benbunan-Fich, 2000; Lock, 2006).

Instructor response to online learning has provided some common themes. A transformation in the expectations of students enrolled in online courses has occurred. Students expect instructor responses to email and discussion boards to occur shortly after the students post their queries (Fox, 2007; Lao \& Gonzales, 2005). Student expectations, increased demands for communication, online course development requirements, and extra attention to detail in an online environment have resulted in increased workloads for faculty of online courses (Papastrergiou, 2006; Rittschof \& Griffin, 2003). Instructors have noted the loss of non-verbal forms of communication in online course delivery formats (Stansfield, McLellan, \& Connolly, 2004). In some learning environments, the loss of the richness provided by various forms of communication has had "a negative impact on the instructional relationship, by making the achievement of instructional objectives more difficult or even impossible" (Farrell, 2000). 
A number of universities offer online programs in educational technology that require skillsbased technology training. Some research indicates that skills-based technology training can be successful through online delivery (Basham, Palla, \& Pianfetti, 2005), but other research indicates that courses requiring significant demonstration of skills by the instructor or hands-on practice by students are difficult to deliver in an online format (Laine, 2003; Reeves, Baxter, \& Jordan, 2003; Willis \& Cifuentes, 2005).

The purpose of the study described in this paper was to investigate differences in student perceptions of a course when offered in a face-to-face format and when offered in a hybrid format with only a few face-to-face classes. The study investigated student-evaluation-of-teaching surveys from a course that required a high level of technology skills development and a significant investment in hands-on practice. Surveys from the course were compared based on the delivery method. Additionally, student-learning preferences and attitudes were examined and described.

This paper describes the methodology used in developing the study including a description of the course examined and the program in which it is contained. Results comparing the students' evaluation of teaching are presented and compared using a Fisher Exact Test. Learning preference groupings were created as a result of observations made during the study and are described after the results are presented. Finally, conclusions derived from the study are discussed.

\section{Methodology}

\section{Course and Masters Program Description}

This study explored student activity, performance, and perceptions in a design and development tools course. The course is part of an educational technology program that was established in the fall of 2002 and is offered as a joint program by the University of South Carolina Aiken and the University of South Carolina Columbia. Six faculty members, three from each campus, serve as the program faculty for the master's degree. At the time of this study, four faculty members were female and two were male. One was a professor, two were associate professors, two were assistant professors, and one was an instructor. The students who have enrolled in the program were $72 \%$ female and $18 \%$ male. The ethnic background of the students were $84 \%$ white, $13 \%$ black, $2 \%$ Asian and $1 \%$ Hispanic. The average age of students at the time of enrollment was 34 years. The youngest enrollee was 22 and the most mature enrollee was 58 .

When the degree was established, the program faculty worked to determine the most appropriate delivery format for each of the twelve courses required to complete the program. Five classes were listed as face-to-face, five as online, and two as hybrid. All of the online classes and the online portions of the hybrid classes used the Blackboard Learning System. In some situations, the faculty enhanced the Blackboard experience with some instructor-created web pages. In the case of face-to-face courses, class meetings were held on each campus. Some courses had separate sections of the class that individually met on each campus, while other courses held the faceto-face meetings with a single instructor at one campus who used two-way, interactive-video to include students from the other campus.

After the first year of the program, the two hybrid classes transitioned to online delivery with two class meetings during the semester. An initial meeting was held to discuss the syllabus and course logistics while a final meeting provided an opportunity for student presentations. One of the face-to-face classes became a videotape class that required occasional class meetings during the semester. After the second year, another face-to-face class became an online class with occasional, optional laboratory time with the instructor. After the fourth year, one of the remaining face-to-face courses moved to an online delivery format with occasional, optional laboratory time. The final two, face-to-face classes became hybrid classes that included four or five meet- 
ings with the instructor during the semester. The hybrid approach for these classes was implemented as a transitional step in the process of moving all of the courses to an online format.

A main purpose for the move of this educational technology program to an online format was to meet the needs of people who indicated a preference for an online format. During the early years of the program, recruiting efforts uncovered that many prospective students were selecting programs at other universities because of the flexibility of an online delivery format. Even though a number of courses in this program required at least some face-to-face meetings, several students with a preference for online courses still enrolled in this program.

As the program progressed, the faculty noted that the performance of some students seemed to change with the course delivery mode. In certain cases, the students' grades differed from course to course and so did their participation and overall effort. Some faculty wondered if these differences were directly related to course delivery mode. In response to the observations and conjectures that were made during the first few years of the program, this study sought to categorize student preferences for the mode of course delivery.

Design and Development Tools II, the second course in a sequence of two, was the course that formed the context for this study. During the Design and Development Tools I course, the students were introduced to a variety of software packages that they used to design educational content. During Design and Development Tools II, students learned to use more advanced features of the software packages while creating educational projects. The software packages included graphics editors, $\mathrm{html}$ editors, and multimedia authoring programs.

During the first four years of the study, Design and Development Tools II was a face-to-face course that met once per week for fifteen weeks during the semester. A number of design principles were presented to direct the development of educational technology projects created by the students. The instructor demonstrated how to use the software tools, and class time was provided for students to engage in guided practice while the instructor was present. The students created a number of individual projects during the semester as they explored the variety of software tools available to them. Near the end of the semester, students worked in groups to create a staff development tutorial that incorporated the software tools they had learned to use through their individual projects. On the final exam day, each group made a brief presentation of its project before the instructor administered a final exam.

During the fifth year of the study, the Design and Development Tools II course was offered in a hybrid format. All course materials were presented through Blackboard and an instructor-created, class website. A number of forums were created on Blackboard including an introduction forum, a logistics forum and a textbook forum. The purpose of the logistics forum was to provide a place to ask logistical questions regarding the course, specific questions about the assignments, or technical questions about the interaction with Blackboard. The logistics forum was the main discussion forum where students were asked to post questions about the assignments. Students were also asked to provide answers to questions from other students if they felt that they were able to provide assistance.

In five face-to-face meetings during the semester, the instructor demonstrated how to use the software tools. Unlike semesters when the entire course was delivered in a face-to-face format, little class time was available for guided practice during the five meetings. Tutorials of some of the necessary software skills were provided through Blackboard. These tutorials were short movie clips that presented animated screen captures with audio descriptions of techniques demonstrated by the instructor. As in the face-to-face course, students created a number of individual projects during the semester. Near the end of the semester, students worked in groups to create a staff development tutorial. On the final exam day, the students gathered one last time in a face- 
to-face environment. Each group made a brief presentation of its project, and then the instructor administered a final exam.

\section{Participants}

Participants for this study enrolled in a design and development tools course in partial completion of a master of education in educational technology program. Students enrolled during the first four years of the study $(n=35)$ were involved in face-to-face classes that met for three hours, once per week for 15 weeks during the spring semester. Students enrolled in the last year of the study $(n=16)$ were enrolled in one of two sections of a hybrid course that had five, face-to-face meet-

\begin{tabular}{|l|c|c|}
\hline \multicolumn{1}{|c|}{ Table 1: Gender \& Ethnic Background } \\
\hline \multicolumn{1}{|c|}{ Category } & $\begin{array}{c}\text { Face to } \\
\text { Face }\end{array}$ & Hybrid \\
\hline Total Participants & 35 & 16 \\
\hline Gender & 26 & 9 \\
\hline Total Females & 9 & 7 \\
\hline Total Males & \\
\hline Ethnic Background & 31 & 13 \\
\hline Total Caucasian Americans & 3 & 3 \\
\hline Total African Americans & 1 & 0 \\
\hline Total Asian Americans & & \\
\hline
\end{tabular}
ings during the spring semester. Other activities were conducted online using Blackboard and an instructor-created website. Information about gender and ethnic background are located in Table 1. Case studies of participants in the last year of the study were used to describe examples of students who fit into one of the five categories defined by the instructor.

\section{Data Collection and Analysis}

Data was collected using the Student Evaluation of Teaching (SET), which was an end-of-course survey administered within the last two weeks of the courses. SET data for students enrolled in the four years when the course was offered in face-to-face format was compared to SET data for students enrolled in the course that was offered in the hybrid format. Not all of the students submitted SETs. Thirty-three students submitted SETs during the face-to-face portion, and fourteen students submitted SETs during the hybrid portion of the study. The course information, requirements and evaluation procedures were consistent throughout the five years of the study with only slight modifications for course improvement each year. The same instructor was responsible for all of the classes that were part of this study.

Initially, the intent of the case study portion of this research was to generate a description of perceptions, activities, and preferences for students enrolled in courses with face-to-face, hybrid, or online delivery modes. During the process of the investigation, the author realized that some students did not seem to have preferences and would perform well in any delivery mode. The author also noted that certain people initially preferred online learning but came to appreciate face-toface class meetings or struggled with the online format. Based on these observations, the author grouped students into one of five categories: prefer online, prefer face-to-face, prefer hybrid, no preference, and online-strugglers.

Each group was personified and given a personal name. The characteristics of members of the group were presented through a description of a single person who represented the group. "Onliner" represented those who preferred online delivery, CUCMe (See You See Me) represented those who preferred face-to-face delivery, and "Hybrid" represented those who preferred a hybrid approach. "Accepter" represented those who had no particular preference for delivery mode, and "Struggler" represented those who indicated a preference for online delivery but struggled to be successful. Further descriptions of each of these groups are provided in the results section.

The instructor assigned students to the groups based on observations in face-to-face environments, evaluation of student online activities, performance in all course activities, stu- 
dent/instructor conversations throughout the course, and perceived preferences in other courses. Student conversations were conducted in an informal manner at various times during the semester so that subjects were unaware that they were participating in a study. This was done in order to remove the possibility of a Hawthorne effect.

Students who demonstrated a desire to enroll in online classes were assigned to either the preferonline group or the online-strugglers group. Their desires were demonstrated through personal interaction with the instructor or comments in online discussions. Students were assigned to the online-strugglers group if their performance was hindered by their apparent struggle with time management or self-discipline to meet the deadlines of the online activities. Students were assigned to the prefer-hybrid group if they expressed an interest in and appreciation for online course delivery. This is much like the online groups except that these students also expressed appreciation for the face-to-face interaction. Students assigned to the two online groups did not demonstrate appreciation for the face-to-face opportunities, so they did not fit the category of prefer hybrid. Students were assigned to the prefer-face-to-face group if they indicated displeasure with online coursework. This displeasure was indicated through personal interaction with the instructor or comments in online discussions. The students who were assigned to the remaining group indicated no preference for delivery mode. These students completed the assignments well and were generally positive in any learning environment.

\section{Results}

The items listed below were included on the SET instrument. Students' responses to these items from 2003 to 2006 can be found in Table 2. Students' responses to these items in 2007 can be found in Table 3. Table 4 contains a summary of the information in Tables 2 and 3 to allow the reader to compare means and standard deviations more easily.

1. The communication of course objectives was:

2. The organization of material presented was:

3. The professor's apparent concern for the students' progress in the course was:

4. In helping me gain valuable knowledge about the subject matter, the professor was:

5. Overall, the teaching of this course was:

6. Satisfaction with the availability of the instructor was:

7. How would you compare the work requirements for this class to that of other similar classes?

\begin{tabular}{|r|r|r|r|r|r|r|r|r|r|}
\hline \multicolumn{10}{|c|}{ Table 2: SET results for face-to-face courses } \\
\hline $\begin{array}{r}\text { Item } \\
\text { No. }\end{array}$ & $\begin{array}{c}\text { Very } \\
\text { Poor }\end{array}$ & Poor & Fair & Good & $\begin{array}{c}\text { Very } \\
\text { Good }\end{array}$ & $\begin{array}{c}\text { Excel- } \\
\text { lent }\end{array}$ & $\begin{array}{c}\text { Mean } \\
\text { n }\end{array}$ & (6ax) & SD \\
\hline 1 & 0 & 0 & 0 & 8 & 10 & 14 & 32 & 5.19 & 0.821 \\
\hline & $0 \%$ & $0 \%$ & $0 \%$ & $25 \%$ & $31 \%$ & $44 \%$ & & & \\
\hline 2 & 0 & 0 & 1 & 11 & 11 & 9 & 32 & 4.88 & 0.871 \\
\hline & $0 \%$ & $0 \%$ & $3 \%$ & $34 \%$ & $34 \%$ & $28 \%$ & & & \\
\hline 3 & 0 & 0 & 3 & 6 & 12 & 12 & 33 & 5.00 & 0.968 \\
\hline & $0 \%$ & $0 \%$ & $9 \%$ & $18 \%$ & $36 \%$ & $36 \%$ & & & \\
\hline 4 & 0 & 0 & 1 & 10 & 11 & 11 & 33 & 4.97 & 0.883 \\
\hline & $0 \%$ & $0 \%$ & $3 \%$ & $30 \%$ & $33 \%$ & $33 \%$ & & & \\
\hline 5 & 0 & 0 & 1 & 9 & 11 & 12 & 33 & 5.03 & 0.883 \\
\hline & $0 \%$ & $0 \%$ & $3 \%$ & $27 \%$ & $33 \%$ & $36 \%$ & & & \\
\hline
\end{tabular}




\begin{tabular}{|c|c|c|c|c|c|c|c|c|c|}
\hline $\begin{array}{l}\text { Item } \\
\text { No. }\end{array}$ & $\begin{array}{c}\text { Very } \\
\text { Dis- } \\
\text { satisfied }\end{array}$ & $\begin{array}{c}\text { Dis- } \\
\text { satisfied }\end{array}$ & $\begin{array}{c}\text { Satis- } \\
\text { fied }\end{array}$ & $\begin{array}{c}\text { Very } \\
\text { Satisfied }\end{array}$ & & & $\mathbf{n}$ & $\begin{array}{c}\text { Mean } \\
\text { (4 Max) }\end{array}$ & SD \\
\hline \multirow[t]{2}{*}{6} & 0 & 1 & 16 & 16 & & & 33 & 3.45 & 0.564 \\
\hline & $0 \%$ & $3 \%$ & $48 \%$ & $48 \%$ & & & & & \\
\hline $\begin{array}{l}\text { Item } \\
\text { No. }\end{array}$ & $\begin{array}{c}\text { No An- } \\
\text { swer }\end{array}$ & $\begin{array}{l}\text { Much } \\
\text { Less }\end{array}$ & $\begin{array}{c}\text { Some- } \\
\text { what } \\
\text { Less } \\
\end{array}$ & $\begin{array}{c}\text { About } \\
\text { the } \\
\text { Same }\end{array}$ & $\begin{array}{c}\text { Some- } \\
\text { what } \\
\text { More } \\
\end{array}$ & $\begin{array}{l}\text { Much } \\
\text { More }\end{array}$ & $\mathbf{n}$ & $\begin{array}{c}\text { Mean } \\
\text { (6 Max) }\end{array}$ & SD \\
\hline \multirow[t]{2}{*}{7} & 0 & 0 & 0 & 28 & 5 & 0 & 33 & 4.15 & 0.364 \\
\hline & $0 \%$ & $0 \%$ & $0 \%$ & $85 \%$ & $15 \%$ & $0 \%$ & & & \\
\hline
\end{tabular}

Table 3: SET results for hybrid course

\begin{tabular}{|c|c|c|c|c|c|c|c|c|c|}
\hline $\begin{array}{l}\text { Item } \\
\text { No. }\end{array}$ & $\begin{array}{l}\text { Very } \\
\text { Poor }\end{array}$ & Poor & Fair & Good & $\begin{array}{l}\text { Very } \\
\text { Good }\end{array}$ & $\begin{array}{c}\text { Excel- } \\
\text { lent }\end{array}$ & $\mathbf{n}$ & $\begin{array}{l}\text { Mean } \\
\text { (6 Max) }\end{array}$ & SD \\
\hline \multirow[t]{2}{*}{1} & 0 & 0 & 2 & 4 & 2 & 6 & 14 & 4.86 & 1.17 \\
\hline & $0 \%$ & $0 \%$ & $14 \%$ & $29 \%$ & $14 \%$ & $43 \%$ & & & \\
\hline \multirow[t]{2}{*}{2} & 0 & 0 & 4 & 2 & 4 & 4 & 14 & 4.57 & 1.22 \\
\hline & $0 \%$ & $0 \%$ & $29 \%$ & $14 \%$ & $29 \%$ & $29 \%$ & & & \\
\hline \multirow[t]{2}{*}{3} & 0 & 3 & 0 & 5 & 1 & 5 & 14 & 4.36 & 1.55 \\
\hline & $0 \%$ & $21 \%$ & $0 \%$ & $36 \%$ & $7 \%$ & $36 \%$ & & & \\
\hline \multirow[t]{2}{*}{4} & 0 & 3 & 2 & 1 & 2 & 6 & 14 & 4.43 & 1.70 \\
\hline & $0 \%$ & $21 \%$ & $14 \%$ & $7 \%$ & $14 \%$ & $43 \%$ & & & \\
\hline \multirow[t]{3}{*}{5} & 0 & 2 & 3 & 1 & 3 & 5 & 14 & 4.43 & 1.55 \\
\hline & $0 \%$ & $14 \%$ & $21 \%$ & $7 \%$ & $21 \%$ & $36 \%$ & & & \\
\hline & $\begin{array}{c}\text { Very } \\
\text { Dis- } \\
\text { satisfied } \\
\end{array}$ & $\begin{array}{c}\text { Dis- } \\
\text { satisfied }\end{array}$ & $\begin{array}{c}\text { Satis- } \\
\text { fied }\end{array}$ & $\begin{array}{c}\text { Very } \\
\text { Satisfied }\end{array}$ & & & & $\begin{array}{c}\text { Mean } \\
\text { (4 Max) }\end{array}$ & SD \\
\hline \multirow[t]{3}{*}{6} & 0 & 3 & 3 & 7 & & & 13 & 3.31 & 0.855 \\
\hline & $0 \%$ & $23 \%$ & $23 \%$ & $54 \%$ & & & & & \\
\hline & $\begin{array}{c}\text { No An- } \\
\text { swer }\end{array}$ & $\begin{array}{l}\text { Much } \\
\text { Less }\end{array}$ & $\begin{array}{c}\text { Some- } \\
\text { what } \\
\text { Less }\end{array}$ & $\begin{array}{c}\text { About } \\
\text { the } \\
\text { Same }\end{array}$ & $\begin{array}{c}\text { Some- } \\
\text { what } \\
\text { More }\end{array}$ & $\begin{array}{l}\text { Much } \\
\text { More }\end{array}$ & & $\begin{array}{c}\text { Mean } \\
\text { (6 Max) }\end{array}$ & SD \\
\hline \multirow[t]{2}{*}{$r_{1}$} & 0 & 0 & 0 & 2 & 5 & 7 & 14 & 5.36 & 0.745 \\
\hline & $0 \%$ & $0 \%$ & $0 \%$ & $14 \%$ & $36 \%$ & $50 \%$ & & & \\
\hline
\end{tabular}

Table 4: SET summary

\begin{tabular}{|r|r|r|r|r|}
\hline \multirow{2}{*}{ Item No. } & \multicolumn{2}{|c|}{ Face-to-face courses } & \multicolumn{2}{c|}{ Hybrid course } \\
\cline { 2 - 5 } & Mean & \multicolumn{1}{c|}{ SD } & Mean & \multicolumn{1}{c|}{ SD } \\
\hline 1 & 5.19 & 0.821 & 4.86 & 1.17 \\
\hline 2 & 4.88 & 0.871 & 4.57 & 1.22 \\
\hline 3 & 5.00 & 0.968 & 4.36 & 1.55 \\
\hline 4 & 4.97 & 0.883 & 4.43 & 1.70 \\
\hline 5 & 5.03 & 0.883 & 4.43 & 1.55 \\
\hline 6 & 3.45 & 0.564 & 3.31 & 0.855 \\
\hline 7 & 4.15 & 0.364 & 5.36 & 0.745 \\
\hline
\end{tabular}


The university assigned scores for the students' overall rating of teaching and the perceived workload for the class. The rating of teaching was item 5 from the SET and the perceived workload for the class was item 7 from the SET. A Fisher Exact Test was conducted to compare student responses

Table 5: Fisher Exact Test - two sided

\begin{tabular}{|l|r|}
\hline \multicolumn{1}{|c|}{ SET Item } & \multicolumn{1}{c|}{$\boldsymbol{p}$-value } \\
\hline Rating of overall teaching & 0.033 \\
\hline Perceived work load & 0.00000072 \\
\hline
\end{tabular}
to these items. The results of the Fisher Exact Test indicated that the rating of overall teaching and the students' perceived workload both had statistically significant differences when comparing scores from students in a face-to-face course with students in a hybrid course (Table 5).

Course grades were calculated using a 100-point, percentage scale. The final grades were then converted to letter grades, which were the grades that were reported to the students. Table 6 shows the frequency of letter grades for students in this study. Additionally, Table 6 shows the means and standard deviations for letter grades after converting them to a 4-point scale. Finally, Table 6 also shows the means and standard deviations for the numerical grades on the original 100 -point scale. A t-test $(\mathrm{p}=0.014)$ showed a statistically significant difference between student grades in courses delivered in a face-to-face format and the course delivered in a hybrid format. (See Table 7.)

\begin{tabular}{|c|c|c|c|c|c|c|c|c|c|c|}
\hline \multicolumn{11}{|c|}{ Table 6: Grade information } \\
\hline \multirow{2}{*}{$\begin{array}{l}\text { Delivery } \\
\text { Method }\end{array}$} & \multicolumn{5}{|c|}{ Letter Grades } & \multirow[b]{2}{*}{$\mathbf{n}$} & \multirow{2}{*}{$\begin{array}{c}\text { Mean } \\
4 \mathrm{pt} \\
\text { scale }\end{array}$} & \multirow{2}{*}{$\begin{array}{c}\text { SD } \\
4 \text { pt } \\
\text { scale } \\
\end{array}$} & \multirow{2}{*}{$\begin{array}{c}\text { Mean } \\
100 \text { pt } \\
\text { scale }\end{array}$} & \multirow{2}{*}{$\begin{array}{c}\text { SD } \\
100 \text { pt } \\
\text { scale }\end{array}$} \\
\hline & $\mathbf{A}$ & B+ & B & $\mathrm{C}+$ & $\mathrm{C}$ & & & & & \\
\hline Face-to-Face & 22 & 5 & 7 & 0 & 1 & 35 & 3.67 & 0.499 & 92.6 & 4.11 \\
\hline Hybrid & 4 & 4 & 4 & 2 & 2 & 16 & 3.19 & 0.680 & 89.1 & 4.51 \\
\hline
\end{tabular}

\begin{tabular}{|l|r|r|}
\hline \multicolumn{3}{|c|}{$\begin{array}{c}\text { Table 7: Course Grades 100-point Scale } \\
\text { Two-sample t-test assuming unequal variances }\end{array}$} \\
\hline & Face to Face & \multicolumn{1}{|c|}{ Hybrid } \\
\hline Mean & 92.6 & 89.1 \\
\hline Variance & 16.9 & 20.5 \\
\hline $\mathrm{n}$ & 35 & 16 \\
\hline df & 27 \\
\hline t Stat & 2.63 \\
\hline P $(\mathrm{T}<=$ t) two-tail & 0.014 & \\
\hline t Critical two-tail & 2.05 & \\
\hline
\end{tabular}

\section{Learning Preference Groupings}

\section{Preference for Online Course Delivery - Case Study: Onliners}

A total of 4 students were identified as having a preference for online learning. Two students provided important insight into students with a preference for online delivery. One was called, "Onliner" and the other was called, "Surprised Onliner."

In this study, Onliner indicated her course-format preference clearly. She lived more than two hours from campus and was very happy when she enrolled in online classes that would not require her to travel nearly five hours in an evening. When she enrolled in face-to-face classes, she worked in a positive way with faculty to avoid having to make the trip to class whenever possible. 
When travel to campus was required, she was very happy to comply and was a model participant. She did very well in both her online and face-to-face activities. She spent time prior to face-toface classes in preparation for the anticipated hands-on activities. She was often prepared with a nearly completed project that she could have completed without the benefit of the face-to-face interaction. Only occasionally did Onliner receive greater benefit from her attendance in the face-to-face classes than she would have achieved in an online format. She was often observed working with other students in class who recognized her abilities, her understanding of the required skills, and her willingness to help because she was often more advanced than other students in the class. In the end, Onliner would have had the same achievement and would have benefited equally well from either an online format or a hybrid format. A complete semester of face-to-face activities probably would have frustrated her because she had the ability to fulfill most of the requirements without face-to-face contact.

Surprised Onliner also indicated that he preferred the online format. His surprise came from the realization that he also developed a great appreciation for the hybrid format. One of the strongest indicators of his preference for online delivery was observed through the sequence of the courses in which he enrolled. The suggested sequence of courses during the program included face-toface courses in the first and second semesters. Surprised Onliner chose to ignore the suggested course sequence and enrolled in the online offerings early in the program, while he enrolled in the face-to-face courses at the end of his program of study. Because of this, he was able to take Design and Development Tools II as a hybrid course during the transitional period from face-to-face to online delivery formats. Some of the online courses required a face-to-face meeting at the beginning of the semester, and some required a second face-to-face meeting at the end of the semester. Surprised Onliner often indicated his online learning preference during the face-to-face meetings, to which he was often tardy. He seemed to have a procrastination and lateness pattern that pervaded even to the online classes. Surprised Onliner freely admitted his struggle with lateness as well as his preference for the online format. Earlier in his program, Surprised Onliner participated in an online course with the same instructor who taught the Design and Development Tools II course in a hybrid format. This was significant because Surprised Onliner had made some conclusions about the instructor based on his experience in the online class. Essentially, Surprised Onliner categorized the instructor as impersonal, stringent, inflexible and uncaring. After a few face-to-face meetings, Surprised Onliner admitted that he had misjudged the instructor. He was surprised to learn that the instructor was very personable, had a friendly sense of humor, and was flexible. Surprised Onliner still categorized the instructor as stringent, but he had a higher appreciation for the stringent policies and their positive effect on the overall delivery of the course. The main reason for the surprise component of his categorization was that he was surprised at how much he appreciated, enjoyed, and benefited from the face-to-face classroom experiences. He indicated that he would not have performed as well had the course been totally online and that he would have missed the opportunity to engage the instructor in a different setting, which enabled him to change his opinion of the instructor. In the end, Surprised Onliner might be considered as part of the group that preferred a hybrid course delivery.

\section{Preference for Face-To-Face Course Delivery - Case Study: CUCMe (See You See Me)}

Three students were assigned to the category of those who preferred face-to-face class meetings. Design and Development Tools II required a high level of technology skill development and a significant investment in hands-on practice. This group of students complained about not having enough time with the instructor and about having to struggle with online activities on their own. One student was selected to represent this group in the case study and was called "CUCMe." 
CUCMe was a veteran, elementary school teacher who had worked to incorporate technology into her classroom. While she had high interest in technology, her technology skills were not as strong as other students in the program. She seemed to be a bit overconfident about her perceived technological ability, which, in turn, caused her more difficulty as she worked to master the required technology skills throughout the course.

CUCMe was always among the last to leave the classroom, which was always well after the scheduled ending time for class. She demanded the most attention during class and also made more electronic inquiries outside of class than other students. She often indicated concern that the pace of the face-to-face class was too hurried and that she required more detailed directions in order to complete her assignments. CUCMe requested and received additional sessions with the instructor; other people in this group joined her during those additional help sessions.

A good example of the need for CUCMe to participate in face-to-face class meetings can be understood through a description of her interaction with the instructor and other students on the discussion board and through email. She was struggling with a particular assignment, and she posted a question about her problem to the discussion board. A fellow student answered her question, but CUCMe responded that the answer did not solve the problem. She explained a little more detail about the problem and requested assistance in finding a solution. After her fourth posting with refinement of the description of her problem, the instructor was finally able to provide a solution that enabled CUCMe to triumph over her dilemma. She received the final response with an adequate solution 57 hours after her initial posting. In the end, the instructor realized that if CUCMe had posed the problem in a face-to-face class, it would have taken less than ten minutes to direct her down the proper path. Instead, CUCMe spent many hours attempting to solve the problem herself, writing messages seeking assistance, and responding to messages she received about her problem.

A short while after this incident, CUCMe sent the following email message to the instructor, "This weekend I became so frustrated with fileshare and the graphics 2 assignment, I questioned my decision to complete this MA [masters degree]. I do not like online courses, especially a media intensive course like this one. So little time is available for actual instruction, we are left to 'figure it out on our own.' I can not figure all this out on my own."

\section{Preference for Hybrid Course Delivery - Case Study: Hybrid}

Three students were assigned to the category of those who preferred a hybrid format. They were generally positive about both formats of the class and indicated that the hybrid format was the best approach to take. This group enjoyed the flexibility of the online format but was very eager to meet in the face-to-face setting. The hybrid group indicated that the face-to-face meetings were very important for them to obtain answers to questions that were too difficult to describe through email or discussion board postings.

Hybrid had been a successful teacher for a number of years. He was able to manage his busy teacher's schedule, a family, and his graduate program. He worked diligently to complete his online activities and was very successful in the class. He admitted that there were times when he arrived at a point where he was unsure of the best path forward. During these times, he considered investing time to work out the problem himself, but he recognized that the process could require more time than he was willing to invest. He considered posting a description of his problem to the discussion board but realized that the time and effort to explain adequately the complicated problem he faced would be considerable. Often, he determined that his best and most efficient course of action was to wait for a face-to-face meeting when he could easily obtain direction from the instructor. 
Hybrid appreciated that the hybrid format provided him with the opportunity to solve his problem in face-to-face meetings. He felt that the hybrid course delivery was the best option for him. He enjoyed the flexibility of the online portion and appreciated that he did not have to physically go to the university each week to attend class. However, the few meetings that were available were instrumental in his success during the class.

\section{No Preference for Course Delivery Method - Case Study: Accepter}

Three students were assigned to the category of those who demonstrated no preference for a course delivery format. They were generally positive about both formats of the class but did not indicate that either online or face-to-face was particularly important to them. To the students in this group, any delivery format would have been acceptable.

Accepter was a veteran teacher who had some experience with technology. Like Onliner, she was well prepared for class, often completed assignments early, and was regularly sought after by other students to provide assistance when they were having difficulty. A difference between Accepter and Onliner was that Accepter lived only a few minutes from campus. She was equally happy participating in online activities where she could engage the instructor and fellow students in electronic communication as she was engaging others in a face-to-face setting. Accepter excelled in all of her classes no matter what delivery format was used. She made the best of whatever situation she confronted.

\section{Struggled with Online Course Delivery - Case Study: Struggler}

Three students were assigned to the category of those who struggled with the online format. People in this group indicated a personal preference for or at least a strong interest in online learning. They preferred the flexibility of an online format and would select this delivery method over a face-to-face format. The source of difficulty that caused their struggle was the time management and self discipline required to meet the many deadlines of the online activities. People in this group tended to be overwhelmed with a full-time career, a family, and responsibilities for a graduate course in addition to struggling with procrastination. These same students often performed very well in a face-to-face class where they met with the instructor each week and were able to meet due dates that were at the same time as class meetings. Some of the strugglers indicated that submitting an assignment late through an electronic method was very different from submitting an assignment late when one had to face the instructor in person.

Struggler was a second career teacher. He had worked as an accountant for many years and then retired. He began teaching under a special needs certification program and was in his second year of teaching when he enrolled in Design and Development Tools II. As a fairly new teacher, he found himself spending significant time in lesson planning and grading. He had many important responsibilities vying for his limited time resources. When he completed projects for the course, they were of very high quality. However, more than half of them were submitted after the posted deadline with a few assignments more than three weeks late. He presented his case for the late submission of his assignments; they were the result of his job responsibilities. Since nearly everyone else in the class also had full-time teaching responsibilities, no special consideration was afforded to Struggler. He felt that this particular class required more work than normal. He did not feel that the assignments were too much for him to handle but that they were too time consuming. This caused him to become more frustrated, and, in the end, he did not have positive feelings for the course.

Struggler had similar difficulties with his other online courses, but he was able to perform better in his face-to-face courses. The face-to-face classes included time for instructor demonstrations 
of assignments followed by class time for students to work on the assignments with the benefit of the instructor's presence. His technical ability, understanding of new skills, and success in completing assignments enabled Struggler to complete his work more quickly than most other students in face-to-face classes. In many cases, he was able to complete the assignments during the class time, which enabled him to submit his completed work early in contrast to his habitual lateness with online assignments. While he was a "Struggler" in the online format, he was an "Achiever" when he was in face-to-face classes.

\section{Conclusion}

The Design and Development Tools II course information, requirements, and evaluation procedures were consistent throughout the five years of the study with only slight modifications for course improvement each year. The same instructor was responsible for all of the classes that were part of this study. The main variable was the delivery format of the course. The SET showed that $50 \%$ of students $(n=14,50 \%=7)$ in the hybrid course indicated that there was much more work involved than in their other courses (Table 3). However, none of the students in the face-to-face classes $(n=33)$ indicated that there was much more work. Instead, $85 \%$ indicated that the work level was about the same (Table 2). The results of a two-sided Fisher's Exact Test demonstrated that there was a statistically significant difference between the perceived workload of students in a face-to-face class compared to students in a hybrid class (Table 5). Despite the consistency in the course requirements, students who participated in the hybrid delivery format with fewer face-to-face classes indicated that there was much more work involved than in their other courses.

Students' perception of more work might not be related to the requirements of the assignments but to the effort necessary to fulfill those requirements. In the face-to-face class, the instructor would often interrupt individual, guided practice sessions when noticing multiple students having similar difficulties with certain tasks. The instructor then provided additional instruction that enabled some students to overcome their difficulties and prevented other students from engaging in similar difficulties. In the hybrid class, students had little guided practice time with the instructor nearby. When students engaged in activities that caused difficulties, the instructor was not present to notice the problem and, therefore, could not provide guidance toward a solution. Instead, students having difficulties invested more effort in the assignments in order to overcome those difficulties on their own. When a student recognized a difficulty and decided to seek assistance from the instructor, the response was not immediate like it was in the face-to-face class. Students would continue to devote time investigating solutions while waiting for the instructor to respond. The effort expended whilst waiting for the instructor to respond contributed to the students' perceptions that the hybrid courses required more work.

The instructor also noted that providing instructional support in the online medium required much more time and effort than in a face-to-face setting. Providing assistance to students through email and discussion boards required greater time investments by the instructor than supporting students in a face-to-face setting. The instructor noted that there were many questions that could have been answered in a very short conversation with a student in a classroom environment where the instructor could observe directly the problem the student was experiencing. Using email or a discussion board to communicate a question and an answer that addressed the actual concern of the student often took more time and resulted in increased frustration of both the student and the instructor.

The SET showed that all but one of the students $(n=33)$ in the face-to-face classes rated the teaching as good or excellent (Table 2). Five students in the hybrid classes $(n=14)$ rated teaching as less than good (Table 3). The results of a two-sided Fisher's Exact Test demonstrated that there was a statistically significant difference between the ratings of teaching by students in a face-to- 
face class compared to ratings by students in a hybrid class (Table 5). One possible explanation for this rating difference might be that the instructor was not as proficient in online or hybrid instruction as with face-to-face instruction. While this could be the case, the instructor received nearly all good and excellent ratings for teaching from students enrolled in a different online class. It appeared from this study that the difference was not related to the instructor but because of the content of the course. The Design and Development Tools II course required a high level of technology skills development and a significant investment in hands-on practice, whereas the other online course taught by the same instructor did not require learning any new, technology skills. The findings of this study were consistent with other research that indicated that courses requiring significant demonstration of skills by the instructor or hands-on practice by students were difficult to deliver in an online format (Laine, 2003; Reeves et al., 2003; Willis \& Cifuentes, 2005).

Ratings by students in all of the other areas of the SET instrument showed similar differences between the face-to-face and hybrid courses (Table 2, Table 3). The overall satisfaction, perception of the instructor's proficiency and perception of personal performance were lower for the hybrid course.

The perception of lower personal performance by students in the hybrid course was confirmed by the lower achievement of these students than students in the face-to-face courses (Table 6). Lower achievement might be related to the students' perception that the hybrid course required more work. The additional time and effort required for students to overcome difficulties might have interfered with the students' attention to detail and ability to complete the highest quality assignments possible. Students were provided feedback and evaluation throughout the semester, so they were aware of their performance in the class at the time the student evaluations of teaching were completed. . Students with lower grades who felt that the course required more effort than other courses may have been frustrated and discouraged at the time the course evaluation forms were administered. Students might have expressed their discontent with the situation through their evaluation of the effectiveness of the instructor.

\section{Learning Preference Groupings}

The case studies presented here offer insight into the different learning styles, preferences, and attitudes of students. Some students will be successful in any educational setting and are equally content to participate in online, hybrid, or face-to-face course delivery formats. Other students prefer the flexibility of an online delivery method and would pursue a program composed of courses delivered in this manner. Despite the many advantages made available by the flexibility of online instruction, some people prefer face-to-face contact with an instructor and other class members. These students perform better, have higher perceptions of the courses. and prefer the advantages provided by face-to-face instruction. Many students prefer a hybrid approach that offers both the flexibility of an online course and the advantages afforded by meeting face-to-face with the instructor and other students. Whenever online instruction is considered, whether for a course that is completely online or for a hybrid course, the instructor should provide guidance and structure that will assist students who have the potential to struggle in an online delivery format.

The groupings identified in this study were intended to provide a framework on which to build a description of learner preferences for modes of course delivery. The groups were personified to allow the reader to imagine an individual that exemplified the characteristics of a particular preference. The classifications do overlap (Figure 1), and some students could be assigned to more than one group. These classifications are not intended to be exhaustive. Other groups could be created to describe different preferences. 


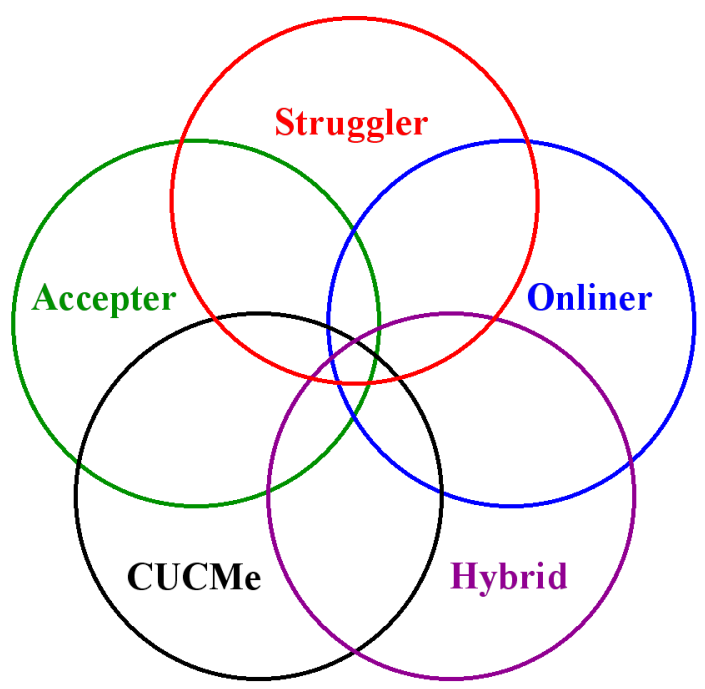

Figure 1: Overlapping nature of preference groups

\section{Course Design Considerations}

Information from this study raises important considerations for faculty who prepare to move faceto-face courses to online or hybrid formats. Of special consideration are courses that require a high level of technology skills development and a significant requirement for hands-on practice. Extra effort on the part of the instructor must be made to provide students with adequate demonstrations of skills and opportunities to practice those skills. Instructors must be prepared to spend time communicating with students as they conduct activities designed to develop skills.

In a face-to-face delivery format, instructors might consider demonstrating specific technology skills to an entire class. During the demonstration, the instructor should entertain questions as well as monitor and adjust to student reactions to the demonstration. Ideally, an instructor should deliver the face-to-face class in a laboratory setting that has a physical setup conducive to classroom presentations. After the demonstration, the instructor should allow for facilitated or guided, hands-on practice to ensure student mastery of the content presented during the demonstration.

In a hybrid delivery format, instructors might consider using the required course time for demonstrating technology skills to the entire class. If time permits, some facilitated or guided practice time should also be provided. If the face-to-face time in a hybrid delivery format is too limited to provide guided practice during scheduled class time, optional laboratory periods might be advantageous to the students. Optional, guided practice, laboratory periods could result in extra workload and effort on the part of the instructor. However, this optional time might also preclude the extra effort that might be necessary to assist struggling students through electronic communication.

In this study, which focused on the hybrid delivery format, students responded positively to movie clips created by the instructor to demonstrate individual skills that could be used to fulfill course requirements. These clips provided content that was similar to content presented during classroom demonstrations. Students indicated that the movie clips were helpful because they could replay the movie clips as needed to master certain skills. They had difficulty remembering the many skills that were presented together in just a few class meetings during the semester. More movie clips demonstrating more skills would provide students with greater opportunities to develop their technological proficiency as they create their assigned projects.

In an online delivery format, instructors should certainly consider providing movie clips to demonstrate specific technology skills. Without the benefit of observing demonstrations of technol- 
ogy skills in a face-to-face format, the movie clips would likely be the predominant method for the instructor to provide the demonstrations to the students.

Finally, instructors in a face-to-face delivery format might also consider augmenting the classroom activities by providing students with access to movie clips that demonstrate the same skills presented during class time. Some students might take advantage of these clips and have greater opportunity to master the technology skills required for success in the course.

These discussions have concentrated on including demonstrations, both live and through movie clips, as part of the course design. A variety of other course design options could be considered in order to improve learning in courses that require technology skills development. One course requirement that was not discussed but was included in the Design and Development Tools II course was group work. Group work has had mixed responses from the students as indicated through open-ended questions on evaluation forms. The open-ended questions did not specifically ask about group work but did ask about general aspects of the course. Some students have indicated their appreciation while others have indicated their lack of appreciation for group work. Some have indicated that the group work activities helped them to improve their skills by providing an avenue of assistance through other group members.

Other considerations for activities to incorporate in courses might include: peer tutoring, discussion board topics, on-line modules that provide additional assistance to students who are struggling, and mentoring relationships.

\section{Limitations}

The limitation of a small sample size within one graduate course in one field of study is an important consideration. While the sample used in this study might provide some insight into student performance, perceptions, activities, and preferences; the generalizability to larger populations should only be made along with a consideration of the limitation of the size of this sample.

This study concentrated on the mode of delivery as the main factor influencing student perception and achievement in the course. Other factors could have influenced the results such as: previous online course experience, proficiency with a particular classroom management system (Blackboard), work experience, or other student demographics.

\section{Future Study}

This study compared face-to-face delivery and hybrid delivery of one particular course that required significant demonstration of skills by the instructor and hands-on practice by students. A future study that included a course taught completely online in a three-way comparison of instructional approaches would provide further insight into the delivery of courses that require technology skills development of students. Further study that included larger sample sizes and other programs of study would provide more insight into the delivery of courses that require technology skills development. An exploration of other factors that might affect student achievement and perception in online courses would provide interesting insights. These factors might include: gender, age, socioeconomic status, previous online course experience, proficiency with a particular classroom management system (Blackboard), or work experience. Future research into the development of effective, online, multimedia resources would be beneficial to students and instructors. Future study that explores how to identify delivery mode preferences proactively would be beneficial to students as they determine what types of courses to take. 


\section{References}

Allen, I. E., \& Seaman, J. (2006) Making the grade: Online education in the United States, 2006. The Sloan Consortium. Retrieved April 19, 2007, from http://www.sloanc.org/publications/survey/pdf/making the_grade.pdf

Basham, J., Palla, A., \& Pianfetti, E. (2005). An integrated framework used to increase preservice teacher NETS-T ability. Journal of Technology and Teacher Education, 13(2), 257-276.

Bassoppo-Moyo, T. C. (2006). Evaluating eLearning: A front-end, process and post hoc approach. International Journal of Instructional Media, 33(1), 7-22.

Biggs, M. J. G., Simpson, C. G., \& Scott, L. W. (2006). Student perceptions of learning environments. Academic Exchange Quarterly, 10(2), 182-186.

Chen, Y. C. (2005). Evaluating the learning effectiveness of using web-based instructions: An individual differences approach. International Journal of Information and Communication Technology Education, 1(1), 69-82.

DeNeui, D. L., \& Dodge, T. L. (2006). Asynchronous learning networks and student outcomes: The utility of online learning components in hybrid courses. Journal of Instructional Psychology, 33(4), 256-259.

Farrell, J. N. (2000). Long live C-learning. Training \& Development, 54(9), 43-46.

Foster, A., \& Carnevale, D. (2007). Distance education goes public. The Chronicle of Higher Education, 53(34), A49.

Fox, B. (2007). Teaching through technology: Changing practices in two universities. International Journal on E-Learning, 6(2), 187-203.

Heinze, A., \& Procter, C. (2006). Online communication and information technology education. Journal of Information Technology Education 5, 235-249. Retrieved April 25, 2007, from http://jite.org/documents/Vol5/v5p235-249Heinze156.pdf

Hiltz, S. R., Coppola, N., Rotter, N., Turoff, M., \& Benbunan-Fich, R. (2000). Measuring the importance of collaborative learning for the effectiveness of ALN: A multi-measure, multi-method approach. Journal of Asynchronous Learning Networks, 4(2), 103-123.

Huang, H. M. (2002). Student perceptions in an online mediated environment. International Journal of Instructional Media, 29(4), 405-422.

Kim, K., \& Bonk, C. J. (2006). The future of online teaching and learning in higher education: The survey says. Educause Quarterly, 29(4). Retrieved May 31, 2007 from http://www.educause.edu/apps/eq/eqm06/eqm0644.asp?bhcp=1

Laine, L. (2003). Is E-learning E-ffective for IT training? Training \& Development 57(6).

Lao, T., \& Gonzales, C. (2005). Understanding online learning through a qualitative description of professors and students' experience. Journal of Technology and Teacher Education, 13(3), 459-474.

Lock, J. (2006). A new image: Online communities to facilitate teacher professional development. Journal of Technology and Teacher Education, 14(4), 663-678.

MacGregor, C. J. (2001). A comparison of student perceptions in traditional and online classes. Academic Exchange Quarterly, 5(4), 143-148.

Marcketti, S. B., \& Yurchisin, J. (2005). Student perceptions of a hybrid course. Academic Exchange Quarterly, 9(3), 317-320.

Newlin, M. H., Lavooy, M. J., \& Wang, A. Y. (2005). An experimental comparison of conventional and web-based instructional formats. North American Journal of Psychology, 7, 327-336.

O’Neil, K., Singh, G., \& O’Donoghue, J. (2004). Implementing eLearning programmes for higher education: A review of the literature. Journal of Information Technology Education, 3, 314-323, Retrieved May 31, 2007, from http://jite.org/documents/Vol3/v3p313-323-131.pdf 
Papastergiou, M. (2006). Course management systems as tools for the creation of online learning environments: Evaluation from a social constructivist perspective and implications for their design. International Journal on E-Learning, 5(4), 593-622.

Reeves, T., Baxter, P., \& Jordan, C. (2003). Teaching computing courses - computer literacy, business microcomputer applications, and introduction to programming online utilizing WebCT. Journal of Computing Sciences in Colleges, 18(1), 290-300.

Reisetter, M., Lapointe, L., \& Korcuska, J. (2007). The impact of altered realties: Implications of online delivery for learners' interactions, expectations, and learning skills. International Journal on ELearning, 6(1), 55-80.

Richardson, J. C., \& Swan, K. (2003). Examining social presence in online courses in relation to students' perceived learning and satisfaction, Journal of Asynchronous Learning Networks, 7(1), 68-88.

Rittschof, K. A., \& Griffin, B. W. (2003). Confronting limitations of cyberspace college courses: Part I identifying and describing issues. International Journal of Instructional Media, 30(2), 127-141.

Shelley, D. J., Swartz, L. B., \& Cole, M. T. (2007). A comparative analysis of online and traditional undergraduate business law classes. International Journal of Information and Communication Technology Education, 3(1), 10-21.

Singh, P., \& Pan, W. (2004). Factors affecting student adoption of online education. Academic Exchange Quarterly, 8(1), 7-10.

Smart, K. L., \& Cappel, J. J. (2006). Students' perceptions of online learning: A comparative study. Journal of Information Technology Education 5, 201-219. Retrieved April 25, 2007, from http://jite.org/documents/Vol5/v5p201-219Smart54.pdf

Stansfield, M., McLellan, E., \& Connolly T. (2004) Enhancing student performance in online learning and traditional face-to-face class delivery. Journal of Information Technology Education 3, 173-188. Retrieved April 25, 2007, from http://jite.org/documents/Vol3/v3p173-188-037.pdf

Tang, M., \& Byrne, R. (2007). Regular versus online versus blended: A qualitative description of the advantages of the electronic modes and a quantitative evaluation. International Journal on E-Learning, $6(2), 257-266$.

Willis, J., \& Cifuentes, L. (2005). Training teachers to integrate technology into the classroom curriculum: Online versus face-to-face course delivery. International Journal of Technology and Teacher Education, 13(1), 43-63

\section{Biography}

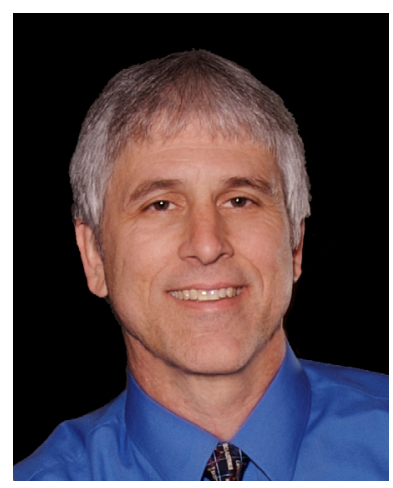

Gary J. Senn is an associate professor of education at the University of South Carolina Aiken in Aiken, SC, USA. He earned his Ph.D. in Science Education - Biology with an emphasis in Educational Technology from the Florida Institute of Technology. His research interests include instructional design and implementation of online learning. He is also the Director of the Ruth Patrick Science Education Center, Director of the DuPont Planetarium, Director of the South Carolina Center of Excellence in Educational Technology and Director of the South Carolina Center of Excellence in Middle-level Interdisciplinary Strategies for Teaching. 